\title{
Disparities in Agricultural Industrial Technology Use between Asia, Africa, and Europe
}

\author{
Eshaq Adofo ${ }^{1}$, Shibab Mukawloon ${ }^{1}$ \\ Mansoura University, Egypt
}

\begin{abstract}
The agricultural industry's advancement by the use of technologies was the correct course of action during the industrial revolution. Optimisation by the application of technologies in the context of improved yield (both in terms of output and quantity) and more effective usage of available capital. The agricultural sector, especially rice farming, provides the majority of farmers in Thailand, Vietnam, and Cambodia with their primary source of income. These three countries have an abundance of natural resources, including fertile rice-growing areas. The Internet of Things (IOT) is used in the Agricultural Internet to link artifacts in our environment to the internet through smartphones or other mobile devices. This complements and advances existing modern agricultural practices, such as irrigation, land management, fertilizer and pesticide application, crop variety production, post-harvest processing, and marketing.
\end{abstract}

Keywords: Agriculture Industry, Technology Applications, and Contemporary Agriculture Introduction

At the moment, the agricultural growth term being created is smart agriculture, also known as smart farming or precision agriculture. This concept refers to the agricultural application of technology. The primary goal of applying this technology is to maximize by increased yields (both in terms of efficiency and quantity) and more effective usage of established capital. In Europe, the agricultural industrial revolution proved to be more dominant. This is because of a demographic disaster, which occurs when the population of productive age is less than the population of non-productive age, forcing the population to be replaced by technology. Meanwhile, in Asia, the industrial revolution has met with limited success, particularly in the agricultural sector. The majority of farmers in Indonesia are over 40 years old, and more than $70 \%$ have only completed elementary school or have no education at all. Due to this lack of structured schooling, agricultural processing expertise is underdeveloped and monotonous. Farmers continue to cultivate agriculture in the traditional manner, without developing new technologies for the purpose of growing plentiful food yields. It cannot be disputed that Asia's population and progress have not been spread equally. This is demonstrated by the fact that the community still has a large amount of untapped land in inland areas, while land in a strategic location is being scrambled at a premium price. Given the skyrocketing price of property, the average area of agricultural land owned by farmers in Indonesia is still very limited. Indeed, since the majority of farmers are unable to operate on their own fields, the findings must be split in half. Additionally, the effect of agricultural land transfer to nonagricultural land, which occurs at a rate of 150-200 thousand acres each year, results in farmers being unable to grow crops. The agricultural sector, especially rice farming, provides the majority of farmers in Thailand, Vietnam, and Cambodia with their primary source of income (Yu \& Diao 2011). These three countries have an abundance of natural resources, including rich 
rice-growing regions, such as those in the Mekong River Delta. The Mekong Delta region is frequently referred to as the "rice bowl" due to its significant rice production. Agricultural production is critical in countries that are part of the Mekong watershed area for meeting domestic and export needs. Thailand is currently the world's largest rice manufacturer, led by Vietnam. Cambodia is currently the world's sixth largest exporter, according to a 2012 USDA report. Meanwhile, Indonesia, which is a predominantly agricultural country, can import rice only from these three countries.

The method for moving agricultural management technology from conventional to modern has not been generally adopted by farmers, who continue to favor traditional equipment over sophisticated technology. Apart from cost constraints, a lack of expertise often slows the rate of technological adoption in the agricultural sector as a whole.

The government's position is critical in providing adequate education to farmers so they can advance the agricultural sector in this industrial revolution period. 4.0.0. Some of the activities that should be accomplished include large-scale counseling and demonstrations about the usage of farm equipment fitted with new technologies.

Today's technology has permeated several markets and provided several avenues of access to life. However, technology must be used prudently while still considering the ramifications on a variety of levels. In agriculture, for example, avoid allowing technology to be dominated by a few individuals or destroying the current ecosystem without regard for the environment's equilibrium.

\section{Utilization of Technology from the Asian Agricultural Industry}

Agriculture is a critical sector for economic growth, especially in developing countries in the Southeast Asian zone (Delgado \& Siamwalla, 1997; Reardon et al., 1998; Szirmai \& Verspagen, 2015; ).Three countries, Thailand, Vietnam, and Cambodia, are used in this study to illustrate the agricultural sector's growth. Agricultural production is occasionally the "key" to the economies of all three countries. Agriculture plays a critical role in community and is critical to the economic sustainability of Southeast Asian countries. According to Thailand's Raja Bhumibol Adulyadej, "agriculture is human existence," implying that people's lives are strongly contingent on the agricultural sector.

Apart from contributing to GDP, another benefit of agriculture is its high labor absorption, especially in rural areas. In Thailand, for example, the agricultural sector employed between $38 \%$ and 39\% of the total workforce from 2001 to 2006. (Encyclopedia of the Nations, 2001; Library of Congress, 2007). This sector was also influential in relocating jobs displaced by layoffs during Thailand's 1997-1998 regional economic crisis. Meanwhile, according to World Bank (2005) statistics, approximately $75 \%$ to $85 \%$ of Cambodia's population is employed in agriculture.

Though Thailand, Vietnam, and Cambodia are recognized as rice exporting countries, their rice output is still subject to fluctuations. Rice output dropped to its lowest amount in Vietnam and Cambodia, for example, during the two countries' civil wars. Agricultural land and supporting facilities, such as irrigation canals, have been harmed by the conflict. Rice production gradually recovered and increased after the war's conclusion. Even today, the two countries enjoy a rice surplus, which enables them to develop into regions. 


\section{Agriculture Production Advancements}

Agricultural resources were heavily used during the industrial revolution, including the mechanization of agricultural machinery (tractors, grinders, and rice threshers), the development of irrigation networks, the usage of non-organic fertilizers, insecticides, and high yielding crops, with an estimated annual growth rate of more than 10\% between 1961 and 2002. The pace of growth in tractor usage across all types, including two or four tires (measured in usable horsepower), has risen from approximately 7.5 percent per year prior to the green movement to approximately $14 \%$ per year since the strategy's introduction. However, Indonesia's per-hectare utilization of this input remains low in comparison to these other Asian countries. Without technology, agriculture would be unable to satisfy the demands of an increasing population. The Ministry of Agriculture took the lead in boosting farm production by initiating Agriculture's Industrial Revolution 4.0. Agricultural mechanization is critical to modern agriculture's goal of sustainable food self-sufficiency (Emami et al., 2018; Reisch et al., 2013; Zhan, 2017; Baig \& Straquadine, 2014; Schreer \& Padmanabhan, 2019). Farmers must promote farmer ingenuity and use. It has risen by 2,000 percent in the last year for mechanization and assistance for agricultural machine tools (Alsintan). To contribute to the industrial revolution 4.0, the emerging agricultural industry is experimenting with new business models and technologies, including precision agriculture, vertical farming, and smart farming. Industry 4.0 is enabled by a variety of innovations, including big data, sensors and drones, research systems, the "agricultural internet," and engineered automation.

The Internet of Things is used in the Agricultural Internet to link artifacts in our environment to the internet through smartphones or other mobile devices. This complements and advances existing modern agricultural practices, such as irrigation, land management, fertilizer and pesticide application, crop variety production, post-harvest processing, and marketing (Brodt et al., 2011; Popp \& Hantos, 2011). Agricultural Research and Development Agency unveiled the UPJA Smart Mobile application to further realise the technological revolution 4.0. UPJA Smart Mobile is an Android application that is used to perform land production, cultivation, rice growing, rice harvesting, rice milling, seed selling, grain sales, agricultural machinery operator preparation, agricultural machinery servicing and repair, and Alsintan spare parts sales.

\section{African Agricultural Industrial Technology Use}

Due to Africa's complex and plentiful climate, numerous instances of technology in agriculture and textile development can be found. The Punic time in North Africa saw the industrialization of natural dyes, salt, and olive oil processing.

Archaeologists believe that Punis and Roman North Africa were exporters of such products in ancient times based on the abundance of olive oil remains found in southern Tripoli. North Africans continue to depend heavily on animal-powered plowing and other wheeled equipment. The threshing bed, or Plostellum punicum, is another item of equipment. North African seafarers use certain tools to separate the seeds' skins. Nubia also seems to have developed cotton on a large scale during the Meroitic and Christian times.

Textiles made of cotton, linen, and animal fibers were discovered at the Ballana and Qustul tombs during this time span. Additionally, cotton and linen are present in Merate, Karanog. It's a well-known fact that cotton cultivation needs a significant amount of water. This suggests 
that many areas had advanced mechanical irrigation technologies during this time span. While the Nubians used the invention, it was regarded as an outside force.

According to United Nations (UN) Food and Agriculture Organization (FAO) results, the world population would hit 9.1 billion in 2050. Global food production needs to rise by $70 \%$, and Africa is using emerging technologies to boost agricultural productivity in order to prevent continued hunger. Africa faces a plethora of nutritional challenges. The population continues to rise at a slow pace, despite poor agricultural productivity. This is made worse by climate change and rural-urban displacement, which is decimating the youth agricultural population.

The combination of increased food demand, low yield capacity, and dwindling agricultural land is compelling the agricultural sector to reimagine itself in order to ensure food protection. Agriculture generates more than 30\% of the continent's GDP and hires more than $60 \%$ of the workforce.

Digital technology use is not recent in Africa. African policymakers have utilized a number of economic tools to boost farm production during the past few decades. The impediment is that African farmers prefer to depend on outdated methods that are based on historical standards.

In certain Igbo communities in Nigeria, farmers plant according to the moon phases, and the inconsistency in their yield is attributed to god rather than to their own process, explains Ekekwe Ndubuisi. Not just that, budgetary constraints and a lack of technological mastery have been impediments.

\section{Africa's Startups and Technologies}

African pioneers are now assisting farmers in increasing crop productivity. To improve access, we provide technology education to growers, apply computer programs, networking, opensource applications, and other modern software. Entrepreneurs provide options for small farmers by offering low-cost inputs.

Zenvus, a Nigerian precision agriculture startup, tests and analyzes soil data such as temperature, nutrition, and vegetative health in order to assist farmers in applying the appropriate fertilizers and optimizing irrigation. This method improves agricultural production and decreases input loss by enabling small-scale farmers to adopt data-driven farming practices.

Meanwhile, UjuziKilimo, a Kenyan startup, is transforming farmers into knowledge-based societies with the aim of growing production through precision insights. This enables irrigation to be adjusted and the needs of specific plants to be determined. SunCulture offers drip irrigation equipment that utilizes solar energy to pump water from every direction.

FarmDrive, a Kenyan organization, links uneducated and underserved farmers to credit while also assisting financial institutions in effectively growing their agricultural loan portfolios.

M-Farm in Kenya and AgroSpaces in Cameroon have pricing data to eliminate market inequalities between farmers and consumers, enabling farmers to gain more. Farmerline and AgroCenta, both based in Ghana, are introducing smartphone and web technology to link farmers with guidance, weather predictions, business knowledge, and financial tips.

Through introducing digital payment services, lending networks, and insurance, large multinational firms have attempted to accelerate the digitization of African agriculture. Global corporations, on the other hand, would deal with small startups. Several barriers exist as a 
result of subscription fees, illiteracy issues, linguistic gaps, boundary crossings, and indigenous orthodoxy.

Farmers, consumers, and entrepreneurs have a huge opportunity to improve the quality of food development and usage in Africa through the use of digital technologies. Precision cultivation and productive food supply chains are only two examples of how technology can have significant economic, social, and environmental benefits.

At Qasr Ibrim, just south of Aswan, along the Nile, there is evidence of professional cotton development. Leatherwork and baskets made of palm fiber are also common. As a result, researchers believe the Nubians were familiar with livestock and irrigation. Manuscripts are a vital part of community in West Africa, requiring a wide variety of agricultural activities. Though manuscripts can be found in the country, Timbuktu has the highest concentration of text or paper. Over a million texts have been preserved.

Additionally, some outlets say that the incident affected almost five million people. From paper manufacturers to clerks, women's science, book clips, tanners, factories, and farmers, have been significant players in the development of West African books.

On the East African coast and in Central Africa, salt is also made. They evaporate sea water to create salt in Mkadini, Tanza nia. This activity became widespread in the second millennium BC. Meanwhile, salt with a purity of 97.6 percent is made in Kibiro, Uganda.

Agricultural Industry Technology Transfer from Europe

$\mathrm{ECHO}$ Green would strengthen cooperation between the government, civil society organizations (CSOs), and the private sector in order to promote sustainable farming practices and to ensure women and young farmers are involved in urban planning and land use.

A green economy that is forward-thinking and inclusive of women and youth. ECHO Green may be seen as a tool for regional learning about Sustainable Development (TPB). Women and young people play a critical position in human capital empowerment and are the engines of change in the Information Technology 4.0 period. ECHO Green's mission is to expand the green economy, especially in agriculture as a primary sector, in order to build sustainable employment, achieve food sovereignty and biodiversity, and promote a more equitable strategy for all stakeholders.

The ECHO Green National Program Manager, the project would use digital media to educate beneficiaries in the Padang Pariaman, East Lombok, and Grobogan districts about the Green Economy definition.

Coronaviruses pose a threat to humanity. The Plague Virus teaches us that women and youth must play an active role in securing our future. Without optimizing emerging infrastructure, the pandemic would increase concern in renewable agriculture and disrupt transport, processing, promotion, and usage chains.

The government estimated a rise in food requirements of 1.2 percent in the 2020-2024 National Medium-Term Development Plan. However, poor production and market volatility are significant drawbacks. 6.2.2 Strengthen women's participation and inclusion in politics and growth (1) Strategies 6.3.3 on sustainable natural resource and environmental sustainability, as well as rural spatial planning; and 6.9.9 on rural spatial planning. Participation of youth in growth can be increased. 
The cooperation of the District Governments adds importance to the project, which is consistent with ECHO Green's objectives. ECHO Green's policy and philosophy are consistent with the Government's commitment to use local resources such as fisheries, farmland, and tourism in order to stimulate an equitable and sustainable economy. Meanwhile, ECHO Green is critical because it would inspire young people to work in agriculture, the sector's backbone. This project is intended to increase their involvement in agriculture and technological skills necessary to cultivate it. The ECHO Green initiative is consistent with the Department of Agriculture and Food Security's initiatives. It is anticipated that the useful insights learnt from this project would help to strengthen farmer welfare. A green economy that is equitable is a component of the Sustainable Development Goals. Through implementing the ideals of a green and inclusive economy in the agricultural sector, agricultural production will improve, revenue will be generated, and inequalities and poverty will be reduced. Women and young farmers are critical members of their societies' agricultural communities. By educating them about the usage of new agricultural technologies, food and nutrient availability would be increased. This would contribute to the development of long-term and sustainable agriculture. As a result, this latest initiative would directly impact locals.

\section{Conclusion}

Agricultural mechanization is critical to modern agriculture's goal of sustainable food selfsufficiency. Farmers must promote farmer ingenuity and use. In agriculture, for example, avoid allowing technology to be dominated by a few individuals or destroying the current ecosystem without regard for the environment's equilibrium. Farmers, consumers, and entrepreneurs have a huge opportunity to improve the quality of food development and usage in Africa through the use of digital technologies. Precision cultivation and productive food supply chains are only two examples of how technology can have significant economic, social, and environmental benefits. African pioneers are now assisting farmers in increasing crop productivity. To improve access, we provide technology education to growers, apply computer programs, networking, open-source applications, and other modern software. Entrepreneurs provide options for small farmers by offering low-cost inputs.

\section{References}

Baig, M. B., \& Straquadine, G. S. (2014). Sustainable agriculture and rural development in the Kingdom of Saudi Arabia: implications for agricultural extension and education. In Vulnerability of agriculture, water and fisheries to climate change (pp. 101-116). Springer, Dordrecht.

Brodt, S., Six, J., Feenstra, G., Ingels, C., \& Campbell, D. (2011). Sustainable agriculture. Nat. Educ. Knowl, 3(1).

Delgado, C. L., \& Siamwalla, A. (1997). Rural economy and farm income diversification in developing countries (No. 595-2016-40000).

Emami, M., Almassi, M., \& Bakhoda, H. (2018). Agricultural mechanization, a key to food security in developing countries: strategy formulating for Iran. Agriculture \& Food Security, 7(1), 1-12.

Popp, J., \& Hantos, K. (2011). The impact of crop protection on agricultural production. Studies in Agricultural Economics, 113(1), 47-66. 
Reardon, T., Stamoulis, K., Balisacan, A., Cruz, M. E., Berdegué, J., \& Banks, B. (1998). Rural nonfarm income in developing countries. The state of food and agriculture, 1998, 283356.

Reisch, L., Eberle, U., \& Lorek, S. (2013). Sustainable food consumption: an overview of contemporary issues and policies. Sustainability: Science, Practice and Policy, 9(2), 725.

Schreer, V., \& Padmanabhan, M. (2019). The many meanings of organic farming: framing food security and food sovereignty in Indonesia. Organic Agriculture, 1-12.

Szirmai, A., \& Verspagen, B. (2015). Manufacturing and economic growth in developing countries, 1950-2005. Structural change and economic dynamics, 34, 46-59.

Yu, B., \& Diao, X. (2011). Cambodia's agricultural strategy: Future development options for the rice sector. Cambodia Development Resource Institute (CDRI), Council for Agricultural and Rural Development (CARD), and IFPRI Special Report. Phnom Penh, Cambodia: CDRI, 1284(1283), 1282.

Zhan, S. (2017). Riding on self-sufficiency: Grain policy and the rise of agrarian capital in China. Journal of Rural Studies, 54, 151-161. 